MIDPI

sciforum
MOL2NET, International Conference Series on Multidisciplinary Sciences

06. MODECO-05: Molec. Diversity \& Ecosystems, Puyo, Ecuador-Porto, Portugal-Paris,

\title{
Management of the deep bedding system in pig farming: An alternative to improve production and animal welfare in the Ecuadorian Amazon
}

\author{
Willan Caicedo ${ }^{1,2}$, Diego Ramos ${ }^{1}$, Victor Zhunaula ${ }^{l}$
}

${ }^{1}$ Facultad de Ciencias de la Tierra, Universidad Estatal Amazónica, Puyo, Pastaza, Ecuador

${ }^{2}$ Granja Agropecuaria Caicedo, Puyo, Pastaza, Ecuador

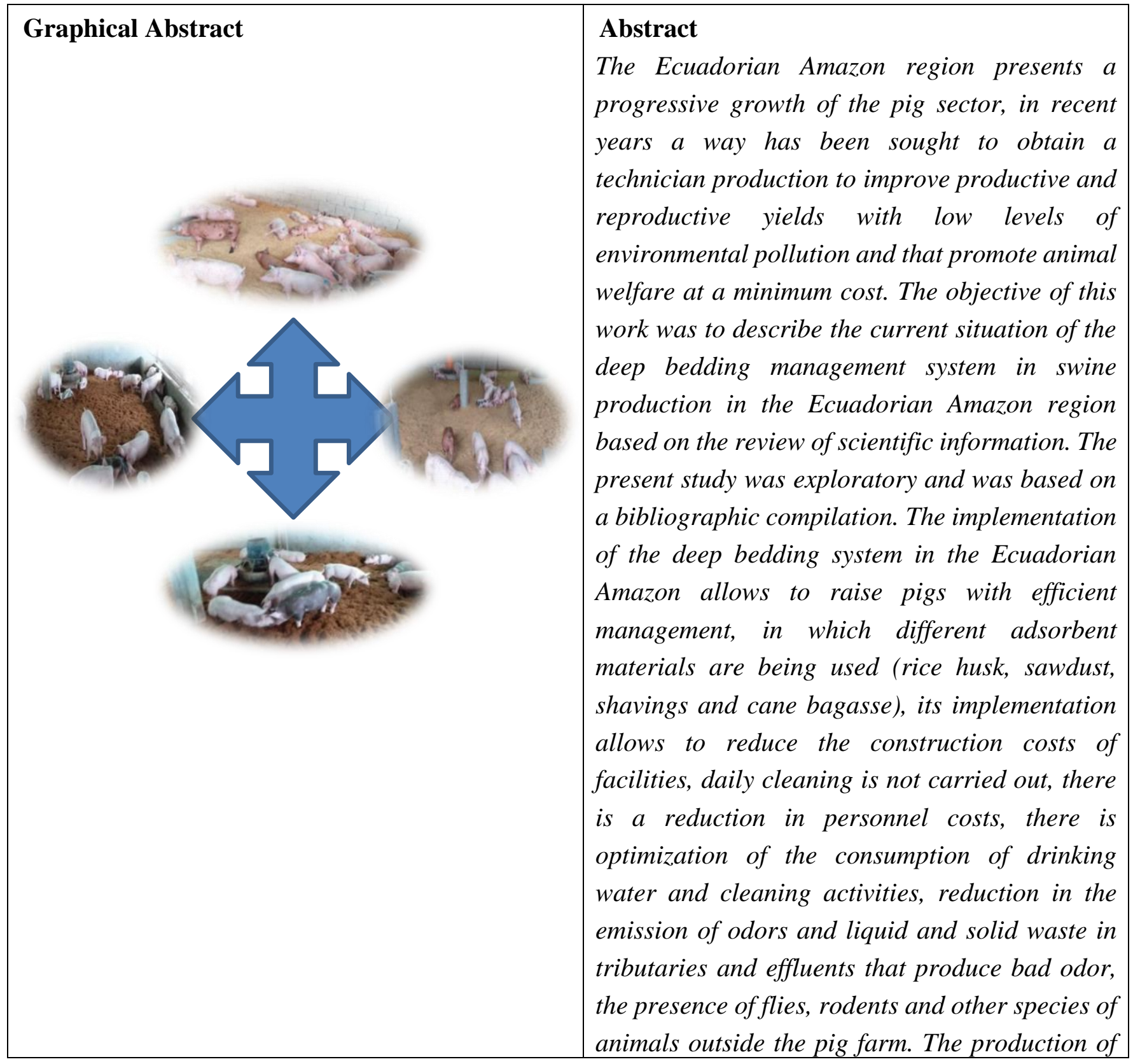


pigs in deep bedding contributes to the improvement of productive indicators, reduces the emission of polluting gases, minimizes the production costs of the system, and guarantees compliance with animal welfare regulations.

Key words: Ecuadorian Amazon, animal welfare, deep bedding, gas emission, productive parameters, system profitability.

\section{Introduction}

In the current scenario, the technicians and small producers in the country, interested in looking for low investment alternatives for the foundation of an adequate infrastructure for the confinement of pigs, find in the deep bedding system a viable technique that consists of the construction of modules or wind tunnels with a mixture of several well dehydrated materials such as hay, rice husk, coffee, sugar cane bagasse, wheat straw, among others (Cruz et al., 2017). The most interesting thing about this system is that it allows the increase in pork meat production with a minimum environmental impact since it reduces both the emission of residues that cause a bad smell, as well as the presence of flies that are carriers of disease-causing pathogens.

On the other hand, the conditions of pig welfare management are an issue that is being implemented worldwide. However, in Ecuador it is necessary to innovate in pig management systems that allow obtaining a maximization of production with minimal impact on the environment and guaranteeing the comfort of the animals (Ramírez, 2017). Medranda and Zambrano (2017) affirm that in the pig exploitation the deep litter management system can be used, which presents less investment, guarantees animal welfare and has low environmental impact compared to traditional systems that are carried out at the level national.

The deep bedding system is a viable option for small pig producers where the concrete floor is changed for a bed of 50 to $60 \mathrm{~cm}$ that can be made of hay, rice husk, cane bagasse, among others, so that pigs have the ability to create micro environments through the material used as a bed. The low water consumption is evident, the low emission of bad odors and the absence of flies are the benefits of the system, in addition to being friendly to the environment (Neira and Danghelo, 2018).

The World Organization for Animal Health refers that in recent years technologies have been developed for intensive pig production, this in order to increase productivity, ignoring respect for the principles of animal welfare, these pass in extreme confinement causing alterations in the quality of the meat and an excessive use of antibiotics that are applied in order to accelerate the production process. At present, consumers demand high nutritional quality in products, thus ignoring the information on the ethical and environmental conditions in which the raw food material is produced (Lourenço et al., 2013). The term animal welfare refers to the way in which it is coupled to different environmental conditions for its development (Barbosa et al., 2017).

\section{Materials and Methods}

This research was exploratory and bibliographic in which information was collected regarding the final weight, back fat, cutlet area, lean meat and carcass performance in the deep bedding and concrete floor system. In addition, in a farm with 100 fattening animals, 50 on a concrete floor and 50 on deep bedding; 
the variables cost of personnel to attend the animals (dollars/day) and time of the animals dedicated to consuming food, drinking and play around (60 minutes) were determined.

\section{Results and Discussion}

The deep bedding system is used to raise pigs with a different handling, said system is made up of absorbent materials, the implementation of deep bedding avoids carrying out daily cleaning compared to concrete or mesh floors, in addition to a good development of well-being animal, this system offers various alternatives since the environment in which they develop is more comfortable (Bautista, 2020). Animals that are raised in deep litter have shown to have better animal welfare behavior with respect to conventional management systems (Alvares, 2016).

Among the indicators evaluated in pigs kept on a concrete floor and deep bedding, final weight, back fat, cutlet area, lean meat and carcass yield are reported (table 1).

Table 1. Characteristics of the carcass of pigs kept in deep bedding and concrete floor

\begin{tabular}{|c|c|c|c|c|c|c|c|}
\hline Parameters & $\begin{array}{l}\text { Initial } \\
\text { weight } \\
\text { (kg) }\end{array}$ & $\begin{array}{l}\text { Final } \\
\text { weight } \\
\text { (kg) }\end{array}$ & $\begin{array}{l}\text { Back fat } \\
\text { (mm) }\end{array}$ & $\begin{array}{l}\text { Cutlet } \\
\text { area } \\
\left(\mathrm{cm}^{2}\right)\end{array}$ & $\begin{array}{l}\text { Lean } \\
\text { meat } \\
(\%)\end{array}$ & $\begin{array}{l}\text { Carcass } \\
\text { performance } \\
(\%)\end{array}$ & References \\
\hline $\begin{array}{l}\text { Deep } \\
\text { bedding }\end{array}$ & 15.7 & 118.4 & 21.8 & 41.3 & 51.1 & 74.9 & $\begin{array}{l}\text { Honeyma } \\
\text { and Harmon, } \\
2003\end{array}$ \\
\hline $\begin{array}{l}\text { Concrete } \\
\text { floor }\end{array}$ & 15.9 & 116.8 & 20.8 & 43.0 & 52.1 & 75.8 & $\begin{array}{l}\text { Cruz et al. } \\
(2009)\end{array}$ \\
\hline
\end{tabular}

Table 2 shows the costs of personnel to care for the animals (dollars/day) and time of the animals dedicated to consuming food, drinking and play around (60 minutes).

Table 2. Personnel costs and welfare indicators of pigs kept in deep bedding and concrete floor

\begin{tabular}{lccc}
\hline Parameters & n & $\begin{array}{c}\text { Costs of personnel to } \\
\text { care for the animals } \\
\text { (dollars/day) }\end{array}$ & $\begin{array}{c}\text { Time of the animals } \\
\text { dedicated to consuming } \\
\text { food, drinking and play } \\
\text { around (60 minutes) }\end{array}$ \\
\hline Deep bedding & 50 & 5 & 40 \\
Concrete floor & 50 & 20 & 15 \\
\hline
\end{tabular}

\section{Conclusions}

The production of pigs in deep bedding improves production indicators, reduces the emission of polluting gases, minimizes the production costs of the system, and guarantees compliance with animal welfare regulations.

\section{References}


- Cruz, E., Almaguel, R., Mederos, C. M., Gonzalez, C., Saez, Y. \& Breña, L. 2017. Evaluación y extensión de la tecnología de las camas profundas en los sistemas de producción porcina del sector campesino y cooperativo en Cuba. Revista Computarizada de Producción Porcina, 19: 495-499

- Ramirez, S. 2017. La producción porcina del país está a la baja. Recuperado el 24 de 07 de 2020 , de revistalideres.ec. Disponible en: https://www.revistalideres.ec/lideres/produccion-porcina-paisestadisticas-baja.html.

- Medranda, D. \& Zambrano, D. 2017. Evaluación de cascarilla de arroz y rastrojo de maíz utilizados en el sistema de cama profunda en la crianza de cerdos. Escuela Superior Politécnica Agropecuaria de Manabí. Manabí- Ecuador.

- Neira, C. \& Danghelo, J. 2018. Camas con subproductos de algarrobo y maíz en cría porcina para la mejora de la calidad del suelo agrícola. Universidad Cesar Vallejo. Lima-Perú. Disponible en: http://repositorio.ucv.edu.pe/bitstream/handle/20.500.12692/35593/Neira_CDJ.pdf?sequence=1

- Lourenço, M., Lisboa, P., Bruna, M., Manzolli, M. C., Gesualdo, M., Barreto, P. \& Guilherme, L. 2013. Bem-estar animal aplicado nas criações de suínos e suas implicações na saúde dos rebanhos. Revista Científica Electrónica de Medicina Veterinaria, 11(21). Disponible en: http://faef.revista.inf.br/imagens arquivos/arquivos destaque/YhtnLpAFRYLxnCV 2013-8-14-15-2347.pdf

- Barbosa, I., Poliana, O., Yngrid, O. \& Zoila, R. 2017. “Bem-estar em suínos: manejo no pré-abate: Revisão". PUBVET, 11(10): 966-969

- Alvares, L.F. 2016. Evaluación de los parámetros productivos en engorde de cerdos, utilizando el sistema de cama profunda con diferente densidad poblacional. Universidad de San Carlos de Guatemala, Guatemala. 